\title{
Clinical, Radiological and Surgical Pitfalls in Fibular Tumors
}

\section{Fibula Yerleşimli Tümörlerde Klinik, Radyolojik ve Cerrahi Tuzaklar}

\author{
Hasan Göçer ${ }^{1}$, Alper Çıraklı², Halil Atmaca ${ }^{3}$, Nevzat Dabak ${ }^{1}$ \\ ${ }^{1}$ Department of Orthopedic and Traumatology, Faculty of Medicine, Ondokuz Mayis University, \\ Samsun, Turkey \\ ${ }^{2}$ Orthopedic and Traumatology Clinic, Kayseri Research and Training Hospital, Kayseri, Turkey \\ ${ }^{3}$ Department of Orthopedic and Traumatology, Faculty of Medicine, Akdeniz University, Antalya, \\ Turkey
}

Dergiye Ulaşma Tarihi: 02/06/2016 Dergiye Kabul Tarihi: 21/07/2016 Doi: 10.5505/aot.2016.50251

\section{ÖZET}

Giriş ve Amaç: Fibula kaynaklı tümörler daha az sıklıkla görülmekle birlikte çoğunun lokal agresif ve malign olmasından dolayı önem arz etmektedir. Fibula kaynaklı tümör nedeniyle tedavi edilen hastalar incelenerek, tanı ve tedavideki tuzak noktalara dikkat çekilmesi amaçlandı.

Yöntem ve Gereçler: Mayıs 2007 ile Haziran 2015 tarihleri arasında fibula yerleşimli tümör nedeniyle tanı ve tedavi edilmiş 36 hasta retrospektif olarak incelendi. Hastaların yaşı, cinsiyeti ve lezyonların lokalizasyonu belirlendi. Tümörün radyolojik özellikleri, histolojik tipi, uygulanan rezeksiyon tipi ve komplikasyonlar incelendi.

Bulgular: Hastaların 20' si kadın, 16' s1 erkek olup yaş ortalaması 31.5 (6-74) yıl bulundu. Fibula 1/3 proksimal bölge $26,1 / 3$ orta bölge $6,1 / 3$ distal bölge 4 hastada tespit edildi. Histolojik olarak tümörlerin 23' ü bening, 9' u malign ve 4' ü metastatik tümördü. Hastaların 19'una intralezyonel küretaj, 15 ' ine geniş rezeksiyon ve 2' sine amputasyon uygulandı.

Tartışma ve Sonuç: Fibula diz eklemi ve ayak bileği stabilitesine katkısı ve proksimalde nörovasküler yapılara yakın komşuluğu nedeniyle birtakım cerrahi zorluklar içermektedir. Radyolojik olarak tümörün sınırları ve ne kadar kemiğin feda edilebileceği iyi planlanmalıdır. İyi bir planlama ve dikkatli bir cerrahi tedavi ile tümörün komplikasyonsuz bir şekilde uzaklaştırılabileceği kanaatindeyiz.

Anahtar Kelimeler: Fibula tümörü, Geniş rezeksiyon, Cerrahi sınır

\section{ABSTRACT}

Introduction: Although fibula based tumors are less common, they are important since a great number of them are local aggressive and malign. The purpose of this study is to evaluate the patients with fibula based tumors and to focus on pitfalls in diagnosis and treatment.

Methods: 36 patients who had been diagnosed with and treated for tumor involving fibula between May 2007 and June 2015 were examined retrospectively. The patients' ages, genders and localizations were specified. Tumor's radiologic features and histological type, type of resection and complications were analyzed.

Results: 20 of the patients were women, while 16 were men and the average age of the patients was 31.5 (6-74) years of age. Tumor was found in fibula $1 / 3$ proximal zone of 26 patients, in fibula $1 / 3$ middle zone of 6 patients and in fibula 1/3 distal zone of 4 patients. Histological, 23 were benign, 9 were malign and 4 were metastatic tumors. Intralesional curettage was performed on 19 patients, wide resection was performed on 15 patients and amputation was performed on 2 .

Discussion and Conclusion: Fibula involves some surgical difficulties because of its contribution to knee joint and ankle stability and its close adjacency to neurovascular structures in proximal. Radiologically, tumor borders and how much bone can be sacrificed should be planned well. With a good planning and a careful surgical treatment, tumor can be removed without complications.

Keywords: Fibula tumor, Wide resection, Surgical margins

Adress for correspondence: Alper Çrrakl, Orthopedic and Traumatology Clinic, Kayseri Research and Training Hospital, Kayseri, Turkey

e-mail:alperomu@gmail.com

Available at www.actaoncologicaturcica.com

Copyright $\mathbb{C}$ Ankara Onkoloji Hastanesi 


\section{Introduction}

Fibular tumors make up $2.4 \%$ of all extremity tumors and most of these are in proximal $1 / 3$. Wide resection is preferred since they are generally composed of local aggressive or malign tumors. However, due to fibula's contribution to joint stability and its close adjacency to important neurovascular structures, it makes surgical interventions more complicated (1). On the other hand, the goal is making sure that the remaining part is functional and creates least morbidity while completely removing the part where the tumor is.

Different resection types are recommended for proximal fibula and the integrity of lateral collateral ligament should be maintained (2). In distal fibula, ligament reconstruction or arthrodesis methods are applied to increase ankle stability $(3,4)$. However, since fibula tumors are rare and since it is not possible to get ideal resection all the time, it may cause some complications such as instability in joints and local relapse in tumor. Although the reason for local relapse is generally the tumor's not being removed completely, there are no studies about the radiological borders of fibula tumors and surgical border $(5,6)$

In this study, we analyzed the fibular tumors we came across in clinic and discussed the clinical difficulties, radiological features and surgical pitfalls with the literature.

\section{Methods:}

After local ethical board permissions were taken, patients recorded in two central tumor archives were scanned between May 2007 and June 2015. Age, gender, and anatomic locations were found. The sizes of tumors were calculated with radiological images such as X-Ray, computerized tomography (CT), magnetic resonance imaging (MRI), whole body bone scintigraphy and thorax CT and later they were compared with the sizes of the removed resection bone. Histopathological type, amount of the resection and complications were found. Patients who did not have files and radiological data, those whose histological types were not known and those who did not receive surgery were not included in the study.

\section{Results:}

36 patients were included in the study. 20 of the patients were women, while 16 were men and the average age of the patients was 31.5 (6-74) years of age. Tumor was found in fibula $1 / 3$ proximal zone of 26 patients, in fibula $1 / 3$ middle zone of 6 patients and in fibula 1/3 distal zone of 4 patients. The patients were divided in two groups as benign and malign (Table 1).

The surgical excision of cases according to fibula localization has been shown in Table 2. Type I excision defined by Malawer et al. (7) was performed on 4 patients while type II excision was performed on 2 patients, modified excision defined by Mootha et al. (8) was performed on 4 patients and above-knee amputation was performed on one patient in wide resection. Wide excision was performed on 3 diaphysis located ewing sarcoma cases and 2 metastasis (Figure 1). Biopsy was made on one lymphoma patient for diagnosis. In patients with fibula distal involvement, osteochondroma excision was performed in 2 , intralesional curettage was performed in one and below-knee amputation was performed in one patient due to relapse of tumor who had previously total distal fibula excision and ankle arthrodesis (Figure 2) (Table 2).

In primary fibula malign tumors, such as especially ewing sarcoma, osteosarcoma and chondrosarcoma, it was found that the tumor continued in 6 of 8 patients within first resection borders when compared with the preoperative

Adress for correspondence: Alper Çrrakl1, Orthopedic and Traumatology Clinic, Kayseri Research and Training Hospital, Kayseri, Turkey

e-mail:alperomu@gmail.com

Available at www.actaoncologicaturcica.com

Copyright $\odot$ Ankara Onkoloji Hastanesi 
tumor sizes. Tumor sizes were measured by radiologicaly before and after operation in Table 3. Radiologically and surgical resection sizes were measured in Table 3 . In one of the patients who were operated, fibula proximal zone was sacrificed, since peroneal nerve and tibialis anterior artery continued in tumor. 4 patients were found to have drop foot, while three of these patients recovered in follow-up period, drop foot has continued in one patient whose fibular nerve was resected. In 2 of the 6 patients who underwent fibula proximal type I and type II excision, knee instability developed. One of these patients was performed lateral collateral ligament (LCL) reconstruction, the other one was followed with above knee bracing. Both patients however, they were amputated due to relapse, which included neurovascular structures.

\section{Discussion:}

With the developments in orthopedic oncology, adjuvant, neoadjuvant chemotherapy and radiotherapy, 5 yearlong patient survival rises from $10 \%$ to $70 \%$ (9). With this increase in survival, it is a must to gain the most functional extremity in the remaining anatomy as well as removing the tumor. Most of the fibula tumors are located proximal section of the bone (10). The benign tumors in this area can be removed without causing too much morbidity. However, since local aggressive and malign tumors need to be removed with wider borders, they may cause knee instability and neurovascular complications. Thus, the anatomy of the area should also be considered while determining the surgical excision. Ligament repair after excision becomes more important (11).

Different resection types have been recommended in fibula proximal zone $(7,11)$. According to Malewer (7) type I resection is performed for benign aggressive, low-grade malignant tumors and metastatic. Type II resection is performed for high-grade malignant tumors, Erler et al. (11) modified Malawer classification by adding two more detailed types of resection. Dieckman et al. (4) claimed that previous classification systems were dependent on the tumour differentiation but not on the tumour size or extension (12). Thus, they reported new classification system. They used this new classification system independent of the surgical margins. Authors stated that, there has to be a proximal area of more than 3-4 $\mathrm{cm}$. of healthy bone in order to preserve the LCL in malignant tumors. If there is less than $3-4 \mathrm{~cm}$. of healthy bone an intraarticular resection of the proximal fibula with the LCL must be cut.

Clinical problems, fibula related pathologies may be neglected in outpatients and give priority to adjacent anatomic structures. Knee joints come to mind first and inside the knee are evaluated $(13,14)$. Tumors, which affect fibular nerve, are evaluated as pitfall neuropathy (15). In cururis middle zone pathologies, tibia is generally evaluated in the foreground and fibular pathologies are neglected. Although distal fibula tumors are less common, lateral malleolus is relatively taken into consideration more while evaluating ankle (16). Thus, we think that distal fibula (lateral malleolus) pathologies are luckier in terms of clinical doubt and diagnosis.

$$
\text { Regarding to radiologic }
$$

diffucuities on evaluation, when pathology about the cururis area comes to mind, images of all anatomical structures should be taken. In plain radiograph, pathologies in fibula proximal zone should not be overlooked while focusing on pathologies inside the joint. Fibula cortical continuity should be followed and its super position with tibia proximal zone should be taken into consideration. MRI helps the measurement of tumor sizes and measurement of intramedullary extension and soft tissue sizes (17). In tumors which extend the cortex, fibular nerve and the

Adress for correspondence: Alper Çıraklı, Orthopedic and Traumatology Clinic, Kayseri Research and Training Hospital, Kayseri, Turkey

e-mail:alperomu@gmail.com

Available at www.actaoncologicaturcica.com

Copyright $\mathbb{C}$ Ankara Onkoloji Hastanesi 
anterior tibial artery in its medial should be assessed and its association with the tumor should be revealed. In their study on 316 patients with tumor, Panicek et al. (18) reported that MRI was not better than CT. There are also studies which show that MRI is better than PET CT (17). Grimmer et al. (9) reported that insufficient marginal excision was higher in fibular osteosarcomas. In these study, resection which passed from $2 \mathrm{~cm}$. away from the sizes measured according to radiological images were performed in 8 patients due to primary malign fibula tumor. In our malign fibula tumor cases, preoperative radiological measurements were not found to be parallel to our intraoperative frozen section. The reason for this may be the fact that fibula has narrower and more spiral medulla when compared with femur and tibia. In bones with a narrow medulla such as fibula, medulla extended tumors such as ewing sarcoma and osteosarcoma should be given more attention. Frozen section should be performed from surgical margins and resection should be made from wider margins when necessary. Surgical margin check should be made in patients who had curettage, resection and excision due to benign or local aggressive fibula tumor.

Surgical difficulties on treatment, proximal zone is less experienced since it is less common in orthopedic oncology when compared with other bones. In fibula proximal local aggressive and malign tumors, type II resection is recommended; however, this surgery should be performed very carefully (7). An especially deep branch of peroneal nerve has motor functions and it should be protected to the utmost. However, it can be sacrificed in cases if the nerve is surrounded in malign tumors (19). In the unplanned and careless surgeries of this area, peroneal nerve injury, artery-vein injury and knee instability may develop (10). Peroneal nerve injury was seen in 4 of the 26 patients with fibula proximal zone tumor. One of these patients developed permanent drop foot since peroneal nerve was not protected due to tumor, the other three patients had complete recovery. Modified resection technique has been defined in fibula proximal zone osteochondroma in order to protect LCL (8). LCL reconstruction should be performed to prevent knee instability. In two of the patients who extended to fibula proximal, knee instability developed. Two was treated with LCL reconstruction, while the other was treated with above knee bracing. Since artery is more resistant to invasion and more important than vein, it may be protected more (20). In case of need, the association between vascular structuretumor should be examined in lumen invasion or thrombus with advanced techniques such as CT angio (21). While chemotherapy and radiotherapy can decrease with efficient use, amputation may be a treatment option in malign tumors with posterior tibial artery and tibial nerve invasion (22). Amputation was performed on our two patients who had undergone surgery due to giant cell tumor and chondrosarcoma after a relapse which surrounded neurovascular structures was found.

In fibula $1 / 3$ middle diaphysis involved tumor excision, knee and ankle stability is not much affected (23). Morbidity of excision in this area is less and more reliable surgical excision can be made. There is medial arterial collateral sirculation in the medial of fibula diaphysis area. This collateral circulation should be protected if vascular invasion is not. In diaphysis located tumors, the narrowness of medulla and the insufficiency of images should be taken into consideration and frozen should be performed and in case of positive margin, the margins of the resection should be extended to safer borders.

Distal fibula tumors are rare and when compared with the proximal zone, its

Adress for correspondence: Alper Çıraklı, Orthopedic and Traumatology Clinic, Kayseri Research and Training Hospital, Kayseri, Turkey

e-mail:alperomu@gmail.com

Available at www.actaoncologicaturcica.com

Copyright $\odot$ Ankara Onkoloji Hastanesi 


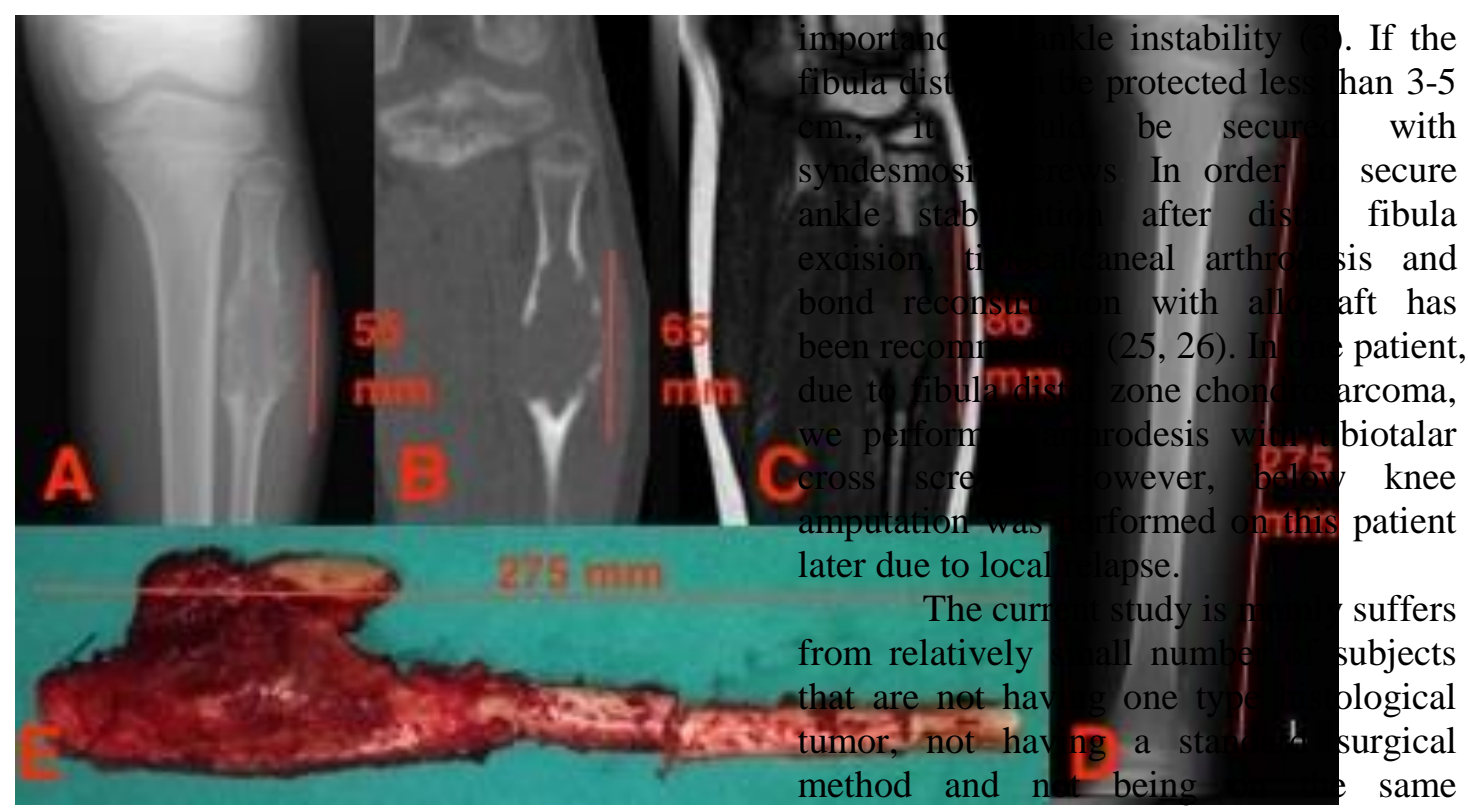

Figure 1: Size of fibula proximal 1/3 located Osteosarcoma. Preoperative imaging A. X-ray, B. CT, C. MRI, Postoperative imaging D. Xray, E. intraoperative view.

anatomical region. Nonetheless, the present study includes information that might be a reference for the future studies, which will perform dynamic, prospective, case control studies on knee and ankle biomechanics.

As a conclusion, Fibula involves

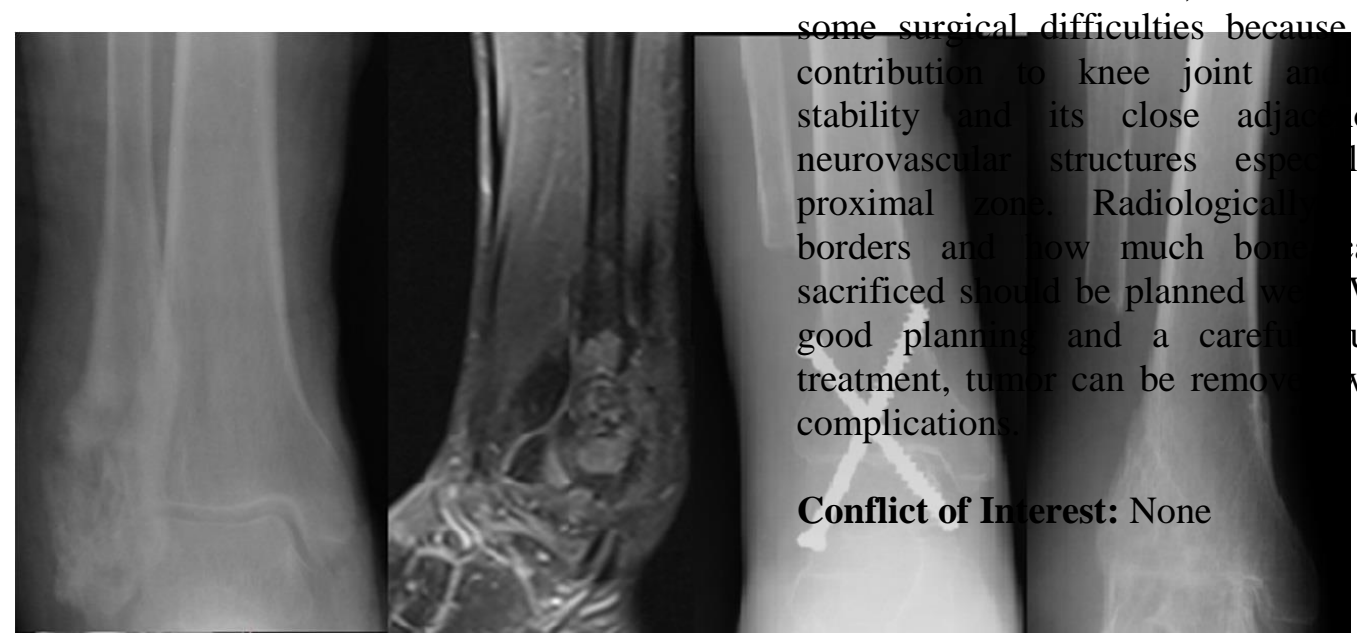

Figure 2: Fibula distal chondrosarcoma was excision and ankle arthrodesis.

surgical resection is easier and its prognosis is better due to its being far from neurovascular structures (24). However, it should be protected due to its

Adress for correspondence: Alper Çırakll, Orthopedic and Traumatology Clinic, Kayseri Research and Training Hospital, Kayseri, Turkey e-mail:alperomu@gmail.com

Available at www.actaoncologicaturcica.com

Copyright (C)Ankara Onkoloji Hastanesi 
Table 1: Histopathological types of cases.

\begin{tabular}{|c|c|c|}
\hline \multirow{3}{*}{ Benign bone tumor } & Tumor & Case number \\
\cline { 2 - 3 } & Osteochondroma & 8 \\
\cline { 2 - 3 } & Aneurismal bone cyst & 6 \\
\cline { 2 - 3 } & Giant cell tumor & 3 \\
\cline { 2 - 3 } & Simple bone cyst & 2 \\
\cline { 2 - 3 } & Enchondroma & 2 \\
\hline Malign bone tumor & Osteoid osteoma & 3 \\
\cline { 2 - 3 } & Ewing sarcoma & 3 \\
\cline { 2 - 3 } & Osteosarcoma & 2 \\
\cline { 2 - 3 } & Chondrosarcoma & 1 \\
\cline { 2 - 3 } & Lymphoma & 4 \\
\hline
\end{tabular}

Table 2: The surgical excision of cases according to fibula localization.

\begin{tabular}{|l|c|c|c|}
\hline & Proximal 1/3 & Middle 1/3 & Distal 1/3 \\
\hline Excision (Intralesional curettage) & 15 & 1 & 3 \\
\hline Wide resection & 10 & 5 & - \\
\hline Amputation & 1 & - & 1 \\
\hline Total & $\mathbf{2 6}$ & $\mathbf{6}$ & $\mathbf{4}$ \\
\hline
\end{tabular}

Table 3: Comparison of radiologically measured tumor sizes and tumor sizes with negative resected borders.

OS: Osteosarcoma, EW: Ewing sarcoma, CS: Chondrosarcoma, G: Gender.

\begin{tabular}{|c|c|c|c|c|l|c|c|c|c|}
\hline Case & $\begin{array}{c}\text { Age } \\
\text { Year }\end{array}$ & Histology & G & Side & Localization & $\begin{array}{c}\text { X-ray } \\
(\mathbf{m m})\end{array}$ & $\begin{array}{c}\text { CT } \\
(\mathbf{m m})\end{array}$ & $\begin{array}{c}\text { MRI } \\
(\mathbf{m m})\end{array}$ & $\begin{array}{c}\text { Excisio } \\
\mathbf{n}(\mathbf{m m})\end{array}$ \\
\hline 1 & 10 & OS & M & Left & $1 / 3$ proximal & 60 & 105 & 115 & 250 \\
\hline 2 & 13 & EW & F & Left & $1 / 3$ middle & 90 & 125 & 170 & 270 \\
\hline 3 & 17 & OS & M & Right & $1 / 3$ proximal & 70 & 120 & 145 & 240 \\
\hline 4 & 52 & CS & M & Left & $1 / 3$ distal & 60 & 68 & 73 & 103 \\
\hline 5 & 9 & EW & M & left & $1 / 3$ middle & 80 & 84 & 96 & 175 \\
\hline 6 & 12 & EW & F & Right & $1 / 3$ middle & 65 & 69 & 76 & 145 \\
\hline
\end{tabular}

\section{References:}

Adress for correspondence: Alper Çıraklı, Orthopedic and Traumatology Clinic, Kayseri Research and Training Hospital, Kayseri, Turkey e-mail:alperomu@gmail.com

Available at www.actaoncologicaturcica.com

Copyright (CAnkara Onkoloji Hastanesi 
1. Zhao SC, Zhang CQ, Zhang CL. Reconstruction of lateral knee joint stability following resection of proximal fibula tumors. Exp Ther Med. 2014;7(2):405-10

2. Patil RS, Saindane K, Surwade AP, Chinchole SS. Giant Cell Tumor of Proximal Fibula Treated With En Block Resection: A Case Report. IJHSR. 2015;5(1):398-401

3. Perisano C, Marzetti E, Spinelli MS, Graci C, Fabbriciani C, Maffulli N, et al. Clinical management and surgical treatment of distal fibular tumours: a case series and review of the literature. Int Orthop. 2012;36(9):1907-13

4. Dieckmann $R$, Ahrens $H$, Streitbürger A, Budny TB, Henrichs MP, Vieth V, et al. Reconstruction after wide resection of the entire distal fibula in malignant bone tumours. Int Orthop. 2011;35(1):87-92

5. Leichtle C, Leichtle U, Gärtner V, Schimmel H, Hartmann J, Rudert M. Multiple skeletal metastases from a giant cell tumour of the distal fibula with fatal outcome. J Bone Joint Surg Br. 2006;88(3):396-9

6. Gikas P, Keller S, Boyle R, Stalley P. Principles of the surgical management of bone tumours. Orthopaedics and Trauma. 2015;29(3):160-2

7. Malawer MM. Surgical management of aggressive and malignant tumors of the proximal fibula. Clin Orthop Relat Res. 1984;186:172-81

8. Mootha A, Saini R, Dhillon M, Bali K, Dhatt S, Kumar V. Modified resection technique for proximal fibular osteochondromas. Orthop Traumatol Surg Res. 2011;97(5):569-73

9. Grimer R, Taminiau A, Cannon S. Surgical outcomes in osteosarcoma. J Bone Joint Surg Br. 2002;84(3):395-400

10. Abdel MP, Papagelopoulos PJ, Morrey ME, Wenger DE, Rose PS, Sim FH. Surgical management of 121 benign proximal fibula tumors. Clin Orthop Relat Res. 2010;468(11):3056-62

11. Erler K, Demiralp B, Ozdemir MT, Basbozkurt M. Treatment of proximal fibular tumors with en bloc resection. The Knee. 2004;11(6):48996

12. Dieckmann R, Gebert C, Streitbürger A, Henrichs M-P, Dirksen U, Rödl R, et al. Proximal fibula resection in the treatment of bone tumours. Intl Orthop. 2011;35(11):168994

13. Kwon JH, Han JH, Almeida VR, Kim SH, Park HJ, Nha K-W. Localized Pigmented Villonodular Synovitis of the Proximal Tibiofibular Joint. KSRR. 2014;26(4):249-52.

14. Mhuircheartaigh JN, Lin YC, Wu JS. Bone tumor mimickers: A pictorial essay. Indian $\mathrm{J}$ Radiol Imaging. 2014;24(3):225-36
15. Paprottka FJ, Machens HG, Lohmeyer JA. Partially irreversible paresis of the deep peroneal nerve caused by osteocartilaginous exostosis of the fibula without affecting the tibialis anterior muscle. J Plast Reconstr Aesthet Surg. 2012;65(8):223-5

16. Papagelopoulos PJ, Savvidou OD, Mavrogenis AF, Galanis EC, Shaughnessy WJ, Unni KK, et al. Lateral malleolus en bloc resection and ankle reconstruction for malignant tumors. Clin Orthop Relat Res. 2005(437):209-18

17. Schmidt GP, Schoenberg SO, Schmid R, Stahl $\mathrm{R}$, Tiling R, Becker CR, et al. Screening for bone metastases: whole-body MRI using a 32channel system versus dual-modality PET-CT. Eur Radiol. 2007;17(4):939-49

18. Panicek DM, Gatsonis C, Rosenthal DI, Seeger LL, Huvos AG, Moore SG, et al. CT and MR imaging in the local staging of primary malignant musculoskeletal neoplasms: Report of the Radiology Diagnostic Oncology Group. Radiology. 1997;202(1):237-46

19. Takahashi S, Ogose A, Tajino T, Osanai T, Okada K. Osteosarcoma of the proximal fibula. An analysis of 13 cases in the northern Japan. Ups J Med Sci. 2007;112(3):366-72

20. Holzapfel K, Regler J, Baum T, Rechl H, Specht K, Haller B, et al. Local Staging of Soft-Tissue Sarcoma: Emphasis on Assessment of Neurovascular Encasement-Value of MR Imaging in 174 Confirmed Cases. Radiology. 2015;275(2):501-9

21. Feydy A. Multidetector CT angiography for vascular invasion of musculoskeletal tumorsResponse. Radiological Soc North America 820 Jorie BLVD, Oak Brook, IL 60523 USA; 2007. p. 634

22. Saglik Y, Yildiz Y, Atalar H, Basarir K. Primary angiosarcoma of the fibula: a case report. Acta Orthop Belg. 2007;73(6):799-803

23. Bozkurt M, Yavuzer G, Tönük E, Kentel B. Dynamic function of the fibula. Gait analysis evaluation of three different parts of the shank after fibulectomy: proximal, middle and distal. Arch Orthop Traum Su. 2005;125(10):713-20

24. Lee S, Kim H-S, Park Y-B, Rhie T-Y, Lee H. Prosthetic reconstruction for tumours of the distal tibia and fibula. J Bone Joint Surg Br. 1999;81(5):803-7

25. Sharma S, Wani IH, Gupta N, Mahajan N, Salaria AQ. Giant cell tumor of talus: a case report. Cases J. 2009;2(1):74

26. Gupte CM, DasGupta R, Beverly MC. The transfibular approach for distal tibial osteochondroma: an alternative technique for excision. J Foot Ankle Surg. 2003;42(2):95-8 